\title{
Two observations on the tales of The contendings of Horus and Seth and Truth and Falsehood
}

Marcelo CAMPAGNO

\begin{abstract}
The Contendings of Horus and Seth (Papyrus Chester Beatty I) and The Blinding of Truth by Falsehood (Papyrus Chester Beatty II) -which can be numbered among the most significant texts of the ancient Egyptian literature of the New Kingdom - show a recognized set of common characteristics. Two topics concerning the remarkable similarity between these texts are considered here. On the one hand, the plot of both texts can be clearly linked to the main episodes of the myth that unites the gods Osiris, Isis, Seth and Horus, and the gap between these different literary "realizations" of the myth can be related to the différences de degré recognized by Claude Levi-Strauss in his analysis of the relations between myth (mythe) and tale (conte). On the other hand, a specific feature of the content of both texts is taken into consideration: the quest of judicial solutions for the conflicts in which the main characters engage. In this sense, it is suggested that two different kinds of judicial procedures are present in both The Contendings and Truth and Falsehood, which can be related to the importance of kinship and state "logics" in the internal organization of these texts as well as in the structure of Ancient Egyptian society.

La contienda entre Horus y Seth (Papiro Chester Beatty I) y La disputa de Verdad y Mentira (Papiro Chester Beatty II) -las cuales se hallan entre los textos más significativos de la literatura egipcia del Reino Nuevo-presentan un destacado conjunto de características comunes. Aqui se considerarán dos cuestiones relacionadas con esa notable proximidad entre tales textos. Por un lado, el argumento básico de ambos textos puede vincularse con las secuencias principales del mito que reúne a los dioses Osiris, Isis, Seth y Horus, y la distancia que separa a ambas "realizaciones" literarias del mito puede ser relacionada con las "diferencias de grado" reconocidas por Claude Levi-Strauss en su análisis de los nexos entre mito y cuento. Por el otro lado, se analiza un elemento especifico del contenido de ambos textos: la búsqueda de soluciones judiciales para los conflictos que se suscitan entre los principales protagonistas. En este sentido, se sugiere que tanto La contienda como Verdad y Mentira contienen dos tipos distintos de procedimientos judiciales, que pueden conectarse con la importancia de las "lógicas" del parentesco y del Estado tanto en la organización interna de estos textos como en la estructuración social del Antiguo Egipto.
\end{abstract}

KeY Words: New Kingdom, Egyptian literature, myth, tale, judicial practices, kinship, State

$\mathrm{W}$ ithin the range of what is usually considered to be ancient Egyptian literature and, more specifically, within the texts belonging to the New Kingdom, there is a considerably extended theme: a dispute between two main protagonists, which can takes the form of a discussion or open antagonism, including several kinds of conflict. The identities of the adversaries, certainly, may vary radically: in fact, disputes may be caused by gods (The Contendings of Horus and Seth), kings (The Quarrel of Apophis and Seqenenre), characters with human features (The Tale of Two Brothers), trees (The Dispute between the Orchard Trees), body parts (The Dispute between the Body and the Head), and even "personified abstract concepts" (The Blinding of Truth by Falsehood). Beyond the common theme that all these texts have in common, the first and the last of them seem to share a wider range of characteristics. In this article, I would like to consider, briefly, two topics of different 
nature which are related to that remarkable similarity between The Contendings and the tale of Truth and Falsehood.

First of all, let us consider the plot of each text. The Contendings of Horus and Seth ${ }^{1}$ is one of the richest available accounts of the conflict between both gods in their struggle for the Egyptian kingship. The actions take place in a pre-eminently judicial context: in fact, Horus and Seth appear before the Ennead of the gods presided over by Atum-Re. The Ennead has to establish whether the royal office, after the assassination of Osiris, belongs to his young, under-aged son, or to his brother, whose main attribute is his strength. The process seems never-ending, due to the fact that Seth constantly rejects the hesitant attempts of the Ennead to favor Horus' cause. At intervals various incidents interrupt the legal process, including tests of physical strength and ability to which both contenders are submitted. The contenders employ different strategies -which include all sorts of tricks- to reach the desired kingship, in which both Horus and Seth as well as Isis, mother and strong supporter of the falcon-god, participate. And when everything seems to indicate that there will be no resolution to this dispute, the intervention of Osiris speeds it to a conclusion. From the underworld, he demands that his son Horus be the one to succeed him in the royal office and, after an epistolary exchange with AtumRe, the Ennead recognizes the rightful claim of Horus, and its president decrees that Seth [20 ] should be taken as a prisoner and that his rival should be consecrated as the king of Egypt ${ }^{2}$.

With regard to the tale of Truth and False$\operatorname{hood}^{3}$, much briefer and more fragmented than
The Contendings, there is presented a recognizable first scene in which the brothers Truth and Falsehood ( $\mathrm{MS}^{\mathrm{C}} \mathrm{t}$ and $\mathrm{Grg}$ ) appear before the Ennead, which rules in favor of the latter in a dispute that -seemingly- revolves around a knife of extraordinary qualities and proportions which was alleged to have been possessed by Falsehood, and Truth, the younger brother, was alleged to have damaged or misplaced. Whatever the actual merits of the case, instigated by Falsehood, the Ennead proceeds to blind Truth and establish him as doorkeeper of Falsehood's house. Later, the successful party in the dispute tries to murder Truth, but the latter manages to elude this fate and finally becomes the doorkeeper of the house of a lady (whose name is lost), who falls for Truth, and later conceives his child. Time passes, and the son, discovering his father's identity, decides to vindicate him. He comes up with a plan, which consists of getting Falsehood to seize one of his oxen. When the theft occurs, Truth's son presents the case to the Ennead and, in so doing, describes the ox as being of colossal proportions, larger than the whole of Egypt. Since the Ennead does not believe that such an ox could exist, the youth replies that neither could a knife with the characteristics that Truth had described in the previous trial, and demands that Truth and Falsehood should be tried again. In the end (very fragmentary), everything indicates that (by the mentioning of a punishment exacted upon Falsehood) the son manages to vindicate his father.

Even though a reading focused only on the protagonists' identities might conclude that there is an enormous distance between a narrative about the gods and a text which seems to be a mere tale of fiction, a slightly

1. Manuscript: p.Chester Beatty I (BM 10681). Text: Gardiner, 1931, 8-26; 1932, 37-60. Translations: Lefebvre, 1949, 178-203; Wente, in Simpson, 1972, 108-126; Lichtheim, 1976, 214-223. In Spanish: Rosenvasser, 1947, 29-46; Campagno, 2004, 37-63; López, 2005, 161-181.

2. The tale has been exhaustively analyzed in Campagno, 2004.

3. Manuscript: p.Chester Beatty II (BM 10682). Text: Gardiner, 1932, 30-36; 1935, 1-4. Translations: Gardiner, 1935, 2-6; Lefebvre, 1949, 159-168; Wente, in Simpson, 1972, 127-132; Lichtheim, 1976, 211-214. In Spanish: Rosenvasser, 1947, 23-27; López, 2005, 153-160. 
deeper reading might reveal a remarkable series of characteristics common to both texts. The conflict between Horus and Seth, which, according to the myth, is the product of the previous conflict between Osiris and Seth, is replicated in the dispute between Falsehood and Truth's son, also the result of the previous dispute between Truth and Falsehood ${ }^{4}$. In fact, both Osiris and Seth as well as Truth and Falsehood are presented as brothers and, in both pairings, the first is the older brother while the second is the younger. More particularly, the conflicts in both texts seek to be solved in a judicial manner, before the Ennead. Similarly, in both narratives there are tricks used by each side. And both end with the triumph of the son of the victim of the initial trauma (the death of Osiris; the blinding of Truth) ${ }^{5}$. Furthermore, independently of its specific characterization, in each text there is a fourth, distinct, participant: a woman, who is the mother of the future champion. Thus, there is an equivalence between the four main protagonists of each text: (Osiris $=$ Truth; Seth $=$ Falsehood; Horus $=$ son of Truth; Isis = nameless lady); there also exists a fifth protagonist (The Ennead) and the dynamics of both texts involves an initial conflict (implicit in The Contendings, explicit in Truth and Falsehood) which is then followed by a second, whose outcome is an inverted version of the first one.
Given this significant number of similarities, what specific relation can be traced between one text and the other? On the one hand, both the papyrus Chester Beatty I, in which The Contendings is found, as well as the Chester Beatty II, which contains the tale of Truth and Falsehood, were found in the same context, both being part of the archive of a family of scribes that lived in Deir el-Medina during the Ramesside period ${ }^{6}$. Even though the composition of The Contendings seems to be more recent -it has been indicated that it belongs to the time when Ramesses $\mathrm{V}$ rose to the throne (XX Dynasty), while the text of Truth and Falsehood is usually placed in the times of XIX Dynasty, it is possible to suppose that, within the framework of a common social and cultural context, both texts could have been elaborated from roughly the same linguistic resources $^{7}$. Beyond these contextual coincidences it is nevertheless clear that the specific plot of Truth and Falsehood -in reference to a dispute between two personified abstract concepts ${ }^{8}$ - constitutes a unique text, unprecedented and without previously known stories linked to it; on the contrary, The Contendings is a version of the mythical conflict between Horus and Seth which has a large series of precedents -the first textual references correspond to the Pyramid Texts ${ }^{9}$, but its oral beginnings are likely to date back to Predynastic times- and also of later versions -for example,

4. The general parallelism in the plot of both tales has been noted, among others, by Gardiner (1935, 2-6), Rosenvasser (1947, 10-14), Lefebvre (1949, 159-161), Gwyn Griffiths (1967, 90), Lesko (1986, 100), López (2005, 153-155).

5. Lefebvre $(1949,161)$ and López $(2005,155)$ have remarked the strong differences between the loyal and protective Isis and this unscrupulous lady ("une Isis indigne", according to Lefebvre). However, two facts must be kept in mind: one the one hand, both female characters conceived a child with someone who has suffered the violence exerted by his antagonist (the killing of Osiris; the blinding of Truth); on the other hand, in both tales, there is a revenging son who reacts against his mother (the beheading of Isis by Horus, after the competition of the hippopotami; the consideration implying that the lady should be executed, after the son knows the identity of his father [see below]). Moreover, as indicated by Baines (1996, 374), in both texts, the female character "supplies the necessary link between the generations and motivates much of the action".

6. See Koenig, 1981, 41-43; Pestman, 1982, 155-172; Broze, 1996, 10-11.

7. On the dating of The Contendings in the context of Ramesses V coronation, see Verhoeven, 1996, 347-363. On the dating of Truth and Falsehood in the XIX Dynasty, see Gardiner, 1935, 2.

8. Such is the way in which Lefebvre $(1949,159)$ defines these singular contenders. Gardiner $(1935,6)$ had suggested that the tale might be considered as a kind of allegory. However, as indicated by Gwyn Griffiths $(1967,89-91)$, the text has not an allegorical content but only the names of its two main characters.

9. Regarding the references to the disputes of Horus and Seth from the Pyramid Texts to the works of the Classical authors, see Gwyn Griffiths, 1960. 
those inscribed on the Edfu temple, or the one referred to by Plutarch in De Iside et Osiride- .

In another place, and following a distinction proposed by Jan Assmann, the problem of the relationship between the myth and its literary "realization" has been considered in an analysis of The Contendings ${ }^{10}$. According to Assmann's theory, in the analysis of the myth it is necessary to distinguish two levels: that of the Geno-text, that is, of the myth in itself, to which direct access is not possible; and that of the Pheno-text, in other words, that of the diverse ways (religious, magical, political, literary) by which the myth manifests concretely. In this line of analysis, then, the myth can be recognized as a specific discursive practice, different from other discursive practices which, interacting with the first one, produce the diverse forms of mythical expression. Assmann himself considers the text of The Contendings as a form of literary elaboration of the myth. In fact, as compared with -for instance- the references to the myth of Horus and Seth in the Pyramid Texts, of eminently religious elaboration, the form of the myth that appears in The Contendings is likely to be categorized by applying the criteria of fictionality, intertextuality and reception that Antonio Loprieno defines in order to determine if a text can be assigned to the domain of literature ${ }^{11}$. According to Loprieno, the narrative of The Contendings has to be included into the realm of mythology, the latter defined from two conditions: "the first condition is an inventory of figures associated with the world of the gods but likely to act according to human behavioral patterns; the second condition is the presence of a literary discourse distinct from other realms of written production" 12 . Thus, The Contendings can be recognized as a literary version of the myth, or in other words, as a text that can be framed within the realm of mythological literature ${ }^{13}$.

Given the fact that in Truth and Falsehood there are no direct references to the gods in the myth, does the text correspond to a different literary genre? And if so, is it possible to analyze such a tale in terms similar to those used to consider The Contendings of Horus and Seth? Even though many scholars have underlined the similarities between the myth of Horus and Seth and the main argument in Truth and Falsehood, the absence of the gods in the latter has surely contributed to the fact that this text has been more directly assigned to a specifically literary sphere. John Baines has, nonetheless, affirmed, in reference to texts belonging to the Ramesside period, that Truth and Falsehood constitutes one of "the "mythical» narratives which depart farthest from any direct mythical model or point of reference in the world of the gods" 14 , thus reinstating a relationship -distant as it may be- between this text and the myth. How can this distant rela-

10. See Campagno, 2004, 66-72. On the distinction about the two levels of myth, see Assmann, 1977, 7-43.

11. According to Loprieno, the criterion of fictionality of the literary text refers to its self-referential status, which implies a tacit agreement between the author and the reader regarding the fact that the world presented in the tale need not to coincide with the real world; the criterion of intertextuality refers to the existence of an "universe of texts" to which the tale is linked, implying that a literary text is never in complete isolation, as an absolute autonomous creation of its author; and the criterion of reception indicates that, in order to consider the literary status of a text, there must be some mechanism that allows and warrants its reading and transmission. See Loprieno, 1996, 39-58.

12. Loprieno, 2004, 16.

13. On the mythical or literary status of The Contendings, there is a wide array of different opinions. See, for instance, the perspectives of Oden, to whom " $a$ myth has to have a traditional character; it has to have a plot; and its characters have to be of a certain sort. "The Contendings of Horus and Seth» fits all of these criteria admirably" (1979, 353), and the one of Junge, to whom "Die Geschichte vom Streit der Götter Horus und Seth um die Herrschaft ist nicht der Mythos in literarischer Gestalt, sondern umgekehrt - es ist ein Werk fiktionaler Literatur" (1994, 101).

14. Baines, 1996, 373. Also Loprieno $(1996,50)$ places the tale of Truth and Falsehood in the field of literary mythology. 
tionship between Truth and Falsehood and the myth of Horus and Seth be explained?

I think that, at this point, an observation made by Claude Lévi-Strauss may be of use. Discussing the work of Vladimir Propp about Russian folktales and the relationships between tales (contes) and myths (mythes), LéviStrauss considers that

...le mythographe s'aperçoit presque toujours que, sous une forme identique ou transformée, les mêmes récits, les mêmes personnages, les mêmes motifs, se retrouvent dans les mythes et les contes d'une population. [...] Il n'est pas douteux, cependant, que presque toutes les sociétés perçoivent les deux genres comme distincts, et que la constance de cette distinction s'explique par quelque cause. A notre avis, ce fondement existe, mais il se ramène à une différence de degré qui est double. En premier lieu, les contes sont construits sur des oppositions plus faibles que celles qu'on trouve dans les mythes : non pas cosmologiques, métaphysiques ou naturelles, comme dans ce derniers, mais plus fréquemment locales, sociales, ou morales. En second lieu, et précisément parce que le conte consiste en une transposition affaiblie de thèmes dont la réalisation amplifiée est le propre du mythe, le premier est moins strictement assujetti que le second sous le triple rapport de la cohérence logique, de l'orthodoxie religieuse et de la pression collective ${ }^{15}$.

Lévi-Strauss' consideration may be of interest so long as it outlines that the difference between myth and tale is a différence de degré, and that, within the frame of that gradual difference, there can be room for the transformations of characters and mythical motives, that would tend to be local, social and moral, rather than cosmological, metaphysical and natural. With reference to Truth and False- hood within the myth of Horus and Seth, it can be noticed that the transformation of the gods into the personified abstract concepts of Truth $\left(M^{\top} \mathrm{C}\right)$ and Falsehood (Grg) takes the conflict from a context situated in the world of gods to a deliberately more human one, and from the cosmological to the moral. As Baines himself points out, "the treatment [of Truth and Falsehood] also brings moral elements to the surface, making events into tokens of general moral dilemmas" ${ }^{16}$.

This point makes the link between both texts and the myth of Horus and Seth even more clear. One as much as the other can legitimately be interpreted as literary "realizations" of the same myth. In reference to The Contendings, the presence of the gods themselves makes the mythological dimension of the text more obvious; nevertheless, its literary dimension is also clear, both because of the added non-canonical contents as well as because of the selective use of narrative forms and plays on words evident throughout the text. In regard to Truth and Falsehood, even if the literary aspect seems more apparent than the mythological one, it must be kept in mind that the formal scheme of the tale comes from the mythical canon of the conflicts between Osiris and Seth, and Seth and Horus, and that this distancing may be more readily understood as the gradual distance that separates the tale from the myth. In any case, closer or farther from the mythical topos, The Contendings and the tale of Truth and Falsehood present two forms of what, using Loprieno's terms, it is possible to recognize as a mimetic exploration of the topos ${ }^{17}$, two examples of the specific intellectual activity in Ramesside Egypt.

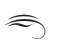

15. Lévi-Strauss, 1973, 153-154.

16. Baines, 1996, 374.

17. According to Loprieno $(1996,55)$, "the application of canonical forms to counter-canonical contents (or vice versa) allows the author to explore the borders of ideology". On the distinction between topos and mimesis, see Loprieno, 1988. 1-21. 
The second topic relating to these two texts that I am interested in highlighting mainly refers to the contents of both tales. Specifically, it concerns the principles that organize the processes by which each conflict is expected to be solved and justice to be re-established. In fact, if there is a common denominator between both texts, it is not only provided by the conflict between their protagonists but also by the quest for a judicial solution to their conflict.

As indicated above, one invariable element in both texts provides a starting point for this analysis. In The Contendings as well as in Truth and Falsehood it is the Ennead which, in its role as a collegiate court, considers the demands of Horus and Seth in their struggle for kingship, those of Falsehood before the hypothetical offence committed by Truth, and those of Truth's son in his determination to vindicate his father. The judicial character of these scenes, a priori, seems clear. And, taking into account when both texts were produced, these scenes might be reminiscent of the judicial procedures effectively carried out by the State courts during the New Kingdom ${ }^{18}$. Nevertheless, it is necessary to advance cautiously here.

The judicial procedures of the Ennead in The Contendings - to which a separate study has been devoted ${ }^{19}$ - are noticeably distant from those celebrated by the State at the time. If anything characterizes the Ennead in [24] this tale, it is its state of continuous tribulation and its inability to impose a verdict whilst displaying a tendency to favor Horus over his opponent. In fact, Seth systematically rejects the attempts to consecrate Horus in his father's throne, and demands a new judi- cial hearing, to which the Ennead repeatedly accedes. On the other hand, it is unable to impose order in the face of the traps that the opponents set for each other in the contests to which they are submitted, and fails even to punish Horus, after he attacks his own mother. This hesitant and perplexed Ennead, as it appears within the frame of the mimesis -that is, of the literary creation of the author of this version of the conflict between Horus and Seth-, does not necessarily imply the presence of an impotent actor in the tale. If this Ennead does not seem to succeed in imposing its will it is because, in the aforementioned episodes, there is no monopoly of coercion, which is an indispensable attribute for a State judicial court.

Such lack of monopoly of coercion on the part of a judicial court, nevertheless, only constitutes an absurd situation in a State judicial context. In non-State societies, in which kinship provides the dominant logic, that monopoly of force is also absent. In such conditions, the ways by which conflicts are solved usually involve extensive negotiations. The leaders and the village councils mediate between the parties, and usually some kind of consensus is reached. But this can be largely delayed, especially in cases in which the parties do not compromise easily. It is this type of conflict-solving logic which -abundantly documented ethnographically and also recognizable in local settings of Ancient Egypt- seems to be operating throughout the most part of the judicial procedures outlined in the narrative ${ }^{20}$. Thus, in the same way that it occurs in non-State societies and Egyptian village communities, the kinship logic occupies a

18. In this respect, see Allam, 1977, 536-553; Lorton, 1977, 2-64; Tyldesley, 2001, 60-76.

19. See Campagno, 2004, 109-137; 2006a, 211-226; 2006b, 20-33.

20. On the judicial procedures in non-State societies and the difficulties to impose verdicts, see Bohannan, 1967, 52-53; Pospisil, 1968, 220-221; Roberts, 1979, 124-125. On the existence of similar judicial practices in local contexts of Ancient Egypt (with reference to the community of Deir el-Medina), see Eyre, 1984, 102; McDowell, $1999,171$. 
relevant place in the structure of the tale of The Contendings.

But the preponderance of such a judicial dynamic associated with kinship does not exclude moments in which a type of formal State judicial system emerges. In this sense, two episodes are significant. One is the physical punishment to which Anty the ferryman is subjected, after he carries Isis to the Island in the Midst, in disobedience to a direct order from the Ennead. And the second is found at the end of the narrative in which, after the intervention of Osiris himself, Atum-Re and the Ennead manage to reduce Seth to the condition of prisoner, imposing a verdict favorable to Horus. These two episodes do not confusingly depart from the predominance of the kinship logic: in relation to the first, because it affects a servant and not the protagonists of the trial; and in relation to the second, because, in that final sequence of the narrative, the kinship logic is displaced from the center of the scene by the State logic, which is the one that finally prevails in the outcome of the conflict. Thus, in the tale of The Contendings it is possible to notice two types of diverging judicial procedures, one associated with the kinship logic and the other with the State logic.

And what happens in the tale of Truth and Falsehood with regard to this kind of process? The Ennead appears here, in the fragmentary beginning as well as in the similarly incomplete end of the text. Despite the lacunae, this Ennead seems to be noticeably different from the one described in The Contendings. In fact, in both episodes, the Ennead appears to be imposing punishment summarily -first to Truth, and then to Falsehood-without leaving room for hesitation or external demands. In the first of them, the execution of the penalty is immediate:

$$
\text { wn.in Grg hr } \underline{d} d, \text {, } n t 3 \text { Ps } \underline{d} t
$$

imy in.tw M3't mtw.tw k3mn t3y.f irty mtw.tw di tw. friry-? n p y.i pr

\section{wn.in t3 Psdt hrirt mi i.dd.fnbt}

Then Falsehood said to the Ennead: «Let Truth [be brought], let him be blinded in both eyes, and let him be given to me as a doorkeeper of my house». And the Ennead did all that he had asked. (2,2-3)

In the second episode, the lacunae are greater, but it is noticeable that Falsehood and Truth's son both pledge oaths to the Ennead $^{21}$, and later a hundred blows and five wounds, a blinding and a reference to the house of Truth (of which Falsehood would have been reduced to the condition of doorkeeper) are all mentioned as punishments inflicted upon the winner of the first dispute. In this sense, despite the summary prosecution, it can be noticed that the Ennead does not proceed to negotiate or seek consensus and is singularly expeditious in the application of the penalties. These procedures, certainly, are much more like those carried out in the State courts than those executed by the Ennead from The Contendings. It could be concluded, thus, that the procedures to establish justice that are established in the tale of Truth and Falsehood were elaborated following an exclusively State model. And it does indeed appear so, in relation to the procedures of the Ennead. But there is a brief passage to which I wish to draw attention.

In the episode of Truth and Falsehood in which Truth's son asks his mother to reveal to him his father's identity, the lady points to the blind doorkeeper, sitting at the entrance to the residence, and indicates that he is his father. The youth's reaction is very significant. He shouts at his mother:

$\breve{s} 3 w n w y t t 3 y . \underline{t} m h(3) y t n r m \underline{t} m t w . t w d i t$

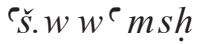


«This deserves that the people of your family be gathered, and that a crocodile be summoned». $(6,1-2)$

What is the meaning of this reaction, seemingly full of indignation? Everything seems to suggest that Truth's son repudiates the fact that his father remains in the deplorable state of blind doorkeeper to the youth's own mother. The son abhors the fact that it is his mother who has had his father reduced to the condition of a servant and, although in a cryptic manner, it seems to signify that the woman should be severely punished. But it must be noticed that, despite the fact that the judicial dynamic associated with the Ennead is decisive in this tale, the youth mentions a noticeably divergent procedure: he calls forth the kin and a crocodile. The incident is obscure, but it is possibly significant.

The allusion to the crocodile seems understandable, if various parallels from other texts are taken into account. It is well known that the crocodile is an animal both revered and feared by the ancient Egyptians, and there are references in which it is mentioned as the instrument of ordained fate (The Doomed Prince) or the actual cause of the death of a person (the end of king Achtoes according to Manetho ${ }^{22}$ ). However, it is in two of the tales in Papyrus Westcar where the presence of a crocodile is shown as more significant. In fact, in one of them, the wife of the priest Ubainer has sexual relations with an individual of low social [26] condition (a $n \underline{d} s$ ) and the priest creates a wax crocodile which becomes real and captures the lover; taken before the king, he decrees that the lover be given to the crocodile and that the woman be delivered to the fire. At the end of another tale, concerning the prodigious birth of the kings of the Fifth Dynasty, a maid attempts -in order to take revenge on her mistress who has beaten her- to declare before the king the prodigies she has witnessed; when she divulges her intention to her own brother, he reacts by striking her, and when the maid goes to the river to fetch water, a crocodile snatches her. Thus it may be that the reference the son of Truth makes to the crocodile in fact refers to the punishment his mother deserves: that of being devoured by the reptile ${ }^{23}$.

Now, what of the kin? Why does Truth's son consider that members of the family should be summoned first, before the crocodile is fetched? Here, the parallels become less obvious. Nevertheless, an element from the previous text perhaps offers some clue. Before the maid is attacked by the crocodile at the river, she finds her brother and outlines her plan to denounce Reddjedet, her mistress. And the brother reacts violently, censoring the idea, reproaching her for involving him and whipping her with a linen stick. Before what the man judges to be a reprehensible act that can be carried out by his sister -for it is an act of disrespect towards the ties of patronage which bind her to Reddjedet-, he punishes her himself (a deed which is then "cosmically" completed as it werewith the crocodile's attack ${ }^{24}$ ). I would like to emphasize here the identity of the person who decides upon and carries out the punishment: a brother.

The situation can be considered from another point of view: according to what was outlined above, testimonies regarding judicial procedures on a local scale in Ancient Egypt converge in the sense that communal affairs were commonly solved within the community, and State justice only intervened in cases when

22. See Manetho, Book I, Fr. 27-28.

23. Such is the conclusion reached by Lefebvre (1940, 23), Rosenvasser (1947, 25 note 7), Wente (1972, 130 note 7), and Lichtheim (1976, 212 note 4). See also Eyre, 1976, 112-113.

24. The connection between the crocodile and a deadly fate for an individual has been considered by Eyre (1976, 103-114). 
the conflict could not be resolved locally or in which the State itself was directly involved ${ }^{25}$. This justice on a local scale seems to have operated in accordance to the prevailing logic of such settings, namely, the kinship logic. This means that, on the global scale of Egyptian society, two judicial procedures coexisted, which operated in different social contexts, according to the predominance of the State logic or the kinship logic. And, beyond these contexts, both logics could have influence on other realms, such as the one concerning the world of the gods, and could also serve as models for the elaboration of narratives concerning the divinities as well as those to do with human society. In fact, it has already been seen how both logics operate conjointly in the structure of The Contendings.

In this sense, it is possible to consider that Truth's son's allusion to the summoning of the family implies that the conduct of his mother should be judged within the framework of such a kinship group ${ }^{26}$. In fact, everything seems to suggest that the youth censors his mother because she ignored the rules that must prevail in the relationships between parents, that is, rules compatible with the kinship logic. And it seems that, when faced with that offence, the tribunal of the Ennead -which here operates according to State procedures- is not the appropriate court. In its place, it is people of the family members who must intervene. As with the brother of Reddjedet's maid, it is the kinship group which can determine the punishment for an offence that, although grave, corresponds to the "domestic" realm ${ }^{27}$.

Thus, both the text of The Contendings and that of Truth and Falsehood show the same duplicity with regard to the principles that govern the procedures to solve conflict and administer justice, a duplicity that is also reminiscent of the coexistence of two logics of social organization in Ancient Egypt, associated with kinship and the State. This common characteristic does not seem a mere coincidence: on the contrary, it seems rather to be anticipated if the same general social and cultural context is taken into account (the community of Deir el-Medina), and the fact that when both texts are compared, (following Lévi-Strauss' argument), there is not a radical divergence but a différence de degré.

25. In this respect, see Théodoridès, 1969b; Trigger, 1993, 47; Allam, 1995, 49; Eyre, 1999, 44; Campagno, $2004,132$.

26. In this sense, see the conclusion of Mat'e: "thus, inasmuch as the son threatens to turn the mother over to a court of her relatives, we can conclude, that a woman who violates the duties of a wife was subject to a court of her kinfolk" (quoted by Franke, 1983, 188).

27. Perhaps something similar can be supposed about an episode registered in the p.BM 10416, in which, faced with a case of adultery, some persons related to the cheated woman pretend to punish the adulterous one and claim: "we are going to beat her, together with her people $(1.3)$ ". Even though Jannsen $(1988,137)$ infers that the group tries to punish the adulterous one as much as her kin, I think that it can be legitimately interpreted that both groups will participate in the punishment of the woman who has broken the rules: it would be, here as well, a punishment that corresponds to the domestic context. With regard to the ways of dealing with adultery, without considering it a "crime" but admitting the violent reaction from the individuals or implicated parties, see Eyre, 1984, 102-103. 


\section{BibLIOGRAPHY}

Allam, S.

1977 Gerichtsbarkeit, in Helck, W., Otto, E. y Westendorf, W. (eds.): LÄ, Wiesbaden, 2, 536-553.

1995 Quenebete et administration autonome en Égypte pharaonique, Revue Internationale des Droits de l'Antiquité 42, 11-69.

Assmann, J.

1977 Die Verborgenheit des Mythos in Ägypten, GM 25, 7-43.

BAINES, J.

1996 Myth and literature, in Loprieno, A. (ed.): Ancient Egyptian Literature. History and Forms, Probleme der Ägyptologie 10, Leiden, 361-378.

BOHANNAN, P.

1967 The Differing Realms of the Law, in Bohannan, P. (ed.): Law and Warfare. Studies in the Anthropology of Conflict, New York, 43-56.

Broze, $\mathrm{M}$.

1996 Mythe et roman en Égypte ancienne. Les aventures d'Horus et Seth dans le Papyrus Chester Beatty I, OLA 76, Leuven.

Campagno, $\mathrm{M}$.

2004 Una lectura de "La contienda entre Horus y Seth», Buenos Aires.

2006a Crimen y castigo en «La contienda entre [28 ] Horus y Seth», in Campagno, M. (ed.): Estudios sobre parentesco y Estado en el Antiguo Egipto, Buenos Aires, 211-226.

2006b Judicial Practices, Kinship and the State in «The Contendings of Horus and Seth», ZAS 133, 20-33.

Eyre, Ch.J.

1976 Fate, Crocodiles and the Judgement of the Dead. Some Mythological Allusions in Egyptian Literature, $S A K 4$, 103-114.
1984 Crime and Adultery in Ancient Egypt, JEA 70, 92-105.

1999 The Village Economy in Pharaonic Egypt, in Bowman, A. and Rogan, E. (eds.): $A g$ riculture in Egypt. From Pharaonic to Modern Times, Oxford, 33-60.

FRANKE, D.

1983 Altägyptische Verwandtschaftsbezeichnungen in Mittleren Reich, Hamburg.

GARDINER, A.H.

1931 The Library of A. Chester Beatty. Description of a Hieratic Papyrus with a Mythological Story, Love Songs, and Other Miscellaneous Texts, $N^{o} 1$ ), London.

1932 Late-Egyptian Stories, Bruxelles.

1935 Hieratic Papyri in the British Museum. Third Series: Chester Beatty Gift, 2 vols., London.

GwYN GRIFFITHS, J.

1960 The Conflict of Horus and Seth from Egyptian and Classical Sources, Liverpool.

1967 Allegory in Greece and Egypt, JEA 53, 79-102.

JANNSEN, J.J.

1988 Marriage Problems and Public Reactions, in Baines, J. et al. (eds.): Pyramid Studies and Other Essays presented to I. E. S. Edwards, London, 134-137.

JUNGE, F.

1994 Mythos und Literarizität: Die Geschichte vom Streit der Götter Horus und Seth, in Behlmer, H. (ed.): ...Quarentes Scientiam. Festgabe für Wolfhart Westendorf zu seinem 70. Geburtstag, Göttingen, 83-101.

KoEnIG, I.

1981 Notes sur la découverte des Papyrus Chester Beatty, BIFAO 81, 41-43. 
LEFEBVRE, G.

1940 Un conte égyptien: Verité et Mensonge, Rd'É 4, 1940, 15-25.

1949 Romans et Contes Égyptiens, Paris.

LESKO, L.

1986 Three Late Egyptian Stories Reconsidered, in Lesko, L. (ed.): Egyptological Studies in Honour of Richard A. Parker, Hannover, 98-103.

LÉvi-Strauss, C.

1973 La structure et la forme. Réflexions sur un ouvrage de Vladimir Propp, in LéviStrauss, C.: Anthropologie Structurale Deux, Paris, 139-173.

Lichtheim, M.

1973 Ancient Egyptian Literature, 1, Berkeley. 1976 Ancient Egyptian Literature, 2, Berkeley.

LÓPEZ, J.

2005 Cuentos y fábulas del Antiguo Egipto, Barcelona.

LOPRIENO, A.

1988 Topos und Mimesis. Zum Ausländer in der ägyptischen Literatur, Wiesbaden.

1996 Defining Egyptian literature: Ancient texts and modern theories, in Loprieno, A. (ed.): Ancient Egyptian Literature. History and Forms, Probleme der Ägyptologie 10, Leiden, 39-58.

2004 Prólogo, in Campagno, M.: Una lectura de «La contienda entre Horus y Seth», Buenos Aires, 13-20.

LORTON, D.

1977 The Treatment of Criminals in Ancient Egypt through the New Kingdom, JESHO 20, 2-64.

McDowell, A.G.

1999 Village Life in Ancient Egypt. Laundry Lists and Love Songs, New York.
ODEN JR., R.

1979 "The Contendings of Horus and Seth" (Chester Beatty Papyrus No. 1): A Structural Interpretation, History of Religions 18, 352-369.

Pestman, $\mathrm{P}$.

1982 Who were the owners, in the «Community of Workmen» of the Chester Beatty Papyri?, in Demarée, R.J. and Janssen, J.J. (eds.): Gleanings from Deir el Medina, Leiden, 155-172.

PospisiL, L.

1968 Law and Order, in Clifton, J. (ed.): Introduction to Cultural Anthropology, Boston.

RoBerts, S.

1979 Order, and Dispute. An Introduction of Legal Anthropology, Oxford.

Rosenvasser, A.

1947 Torneos de acertijos en la literatura del Antiguo Egipto, Buenos Aires.

1976 Introducción a la literatura egipcia. Las formas literarias, RIHAO 3, 7-105.

Simpson, W.K. (ed.)

1972 The Literature of Ancient Egypt. An Anthology of Stories, Instructions, and Poetry, New Haven.

THÉODORIDĖs, A.

1969a Le serment terminal de "Verité-Mensonge", Rd'É 21, 85-105.

1969 b Les ouvriers-“magistrats" en Égypte à l'époque ramesside (XIXe-XXe dyn.; 13e-10e s. av. J.-C.), Revue Internationale des Droits de l'Antiquité 16, 103-188.

TRIGgER, B.G.

1993 Early Civilizations. Ancient Egypt in Context, Cairo. 
TYldesley, J.

2001 Judgement of the Pharaoh. Crime and Punishment in Ancient Egypt, London.

Verhoeven, U.

1996 Ein historischer "Sitz im Leben" für die Erzählung von Horus und Seth des Papyrus Chester Beatty I, in SchadeBusch, M. (ed.): Wege Öffnen. Festschrift für Rolf Gundlach zum 65. Geburstag, Wiesbaden, 347-363.
Wente, E.

1972 The Blinding of Truth by Falsehood, in Simpson, W. K. (ed.): The Literature of Ancient Egypt. An Anthology of Stories, Instructions, and Poetry, New Haven, 127-132.

1972 The Contendings of Horus and Seth, in Simpson, W. K. (ed.): The Literature of Ancient Egypt. An Anthology of Stories, Instructions, and Poetry, New Haven, 108-126. 


\section{Juan Antonio Belmonte}

Instituto de Astrofísica de Canarias

Vía Láctea $\mathrm{S} / \mathrm{N}$

38200 La Laguna, Tenerife - Islas Canarias

España

$$
\text { jba@iac.es }
$$

\section{Marcelo Campagno}

Instituto Multidisciplinario de Historia y Ciencias Humanas

Departamento de Egiptología

Saavedra $15,5^{\circ}$ piso

C1083ACA Buenos Aires

Argentina

mcampagno@fibertel.com.ar

\section{Lucía Elena Díaz-Iglesias Llanos}

Dpto. de Prehistoria, Antropología e Historia Antigua

Facultad de Geografía e Historia - Campus de Guajara

38071 Universidad de La Laguna

Tenerife - Islas Canarias

España

luch68@hotmail.com

\section{Magdi Fekri}

Faculty of Tourism

Minufiya University

El-Sadat City

Egypt

per-ankh@hotmail.com

\section{Cristina Pino Fernández}

cristinapino@telefonica.net 


\section{Mosalam Shaltout}

Helwan Observatory

Helwan, Cairo

Egypt

mosalamshaltout@hotmail.com

\section{Eric P. Uphill}

Institute of Archaeology

University of London

31-34 Gordon Square

London WC1H OPY

United Kingdom

\section{Marie-Paule Vanlathem}

Association Égyptologique Reine Élisabeth Musées Royaux d'Art et d'Histoire

Parc du Cinquantenaire 10

B-1000 Bruxelles

Belgique

mariepaule.vanlathem@belgacom.net 


\section{Trabajos de Egiptología}

\section{Papers on Ancient Egypt}

P

Número 4 2005 


\title{
Consejo Editorial
}

\author{
Miguel Á. Molinero Polo \\ Universidad de La Laguna \\ Antonio Pérez Largacha \\ Universidad de Castilla-La Mancha \\ José-R. Pérez-Accino \\ Birkbeck, Universidad de Londres \\ Covadonga Sevilla Cueva \\ Universidad Autónoma de Madrid
}

\section{Comité Científico}

Josep Cervelló i Autuori

Aula Aegyptiaca, Barcelona

Ma José López Grande

Universidad Autónoma de Madrid

Josep Padró i Parcerisa

Universitat de Barcelona

$\mathrm{M}^{\mathrm{a}}$ Carmen Pérez Die

Museo Arqueológico Nacional, Madrid

Ester Pons Mellado

Museo Arqueológico Nacional, Madrid

José M. Serrano Delgado

Universidad de Sevilla

\section{Colaboradores Editoriales}

Linda Steynor

English editorial assistant

Hervé Mouriacoux

Assistant editoriale pour langue française 
Juan Antonio Belmonte, Mosalam Shaltout, Magdi Fekri

Astronomy and landscape in Ancient Egypt:

Challenging the enigma of the minor step pyramids

\section{Marcelo Campagno}

Two observations on the tales of The contendings of Horus and Seth and Truth and Falsehood

\section{Lucía Elena Díaz-Iglesias Llanos}

Commentary on Heracleopolis Magna from the theological perspective (I):

The image of the local lakes in the vignette of chapter 17 of the Book of the Dead

Cristina Pino Fernández

Prince Ahmose Sapair again

Eric P. Uphill

Irrigation basins and cultivated land under the Twelfth Dynasty

\section{Marie-Paule Vanlathem}

Cléopâtre dans le miroir de la peinture du XIXe siècle 
Trabajos de Egiptología está producida por Isfet. Egiptología e Historia.

c/ Blanco $1,2^{\circ}$

38400 Puerto de la Cruz

Tenerife - Islas Canarias

España

Maquetación: Ignacio Cases

(C) Autores de los artículos aparecidos

y Consejo Editorial de Trabajos de Egiptología - Papers on ancient Egypt

Depósito legal:

ISSN 1695-4750

Impresión: 